\title{
Oil and Debt Management in Nigeria
}

\author{
Ako-Nai R. I. ${ }^{1} \&$ Ayoola A. O. ${ }^{1}$ \\ ${ }^{1}$ Department of International Relations, Obafemi Awolowo University, Ile-Ife, Nigeria \\ Correspondence: Ayoola A. O., Department of International Relations, Obafemi Awolowo University, Ile-Ife, \\ Nigeria. Tel: 234-803-475-4318. E-mail: bukyayoola@yahoo.com
}

Received: July 25, 2012 Accepted: September 20, 2012 Online Published: May 30, 2013

doi:10.5539/jpl.v6n2p178 URL: http://dx.doi.org/10.5539/jpl.v6n2p178

\begin{abstract}
Nigeria's debt at independent was put at about N488.8 million which was mainly long-term development soft loans. The world economic recession and fall in price of oil in 1982 were identified as major factors that led many countries to debt crisis. Nigeria's debt accumulated due to gross mismanagement of resources and loans contracted as well as failure of governments to keep-up with repayment schedules. This paper assesses the management of Nigeria's debt. It examined the role of International Financial Institutions (IFIs) in discussing the politics of Nigeria's debt management vis-à-vis motivational factor behind consideration for loans, disbursement and at what rate?

The paper employed both primary and secondary sources of data. Primary data was sourced from Debt Management Office, National Bureau of Statistics, Central Bank of Nigeria and National Institute for Social and Economic Research while secondary data was sourced from journals, books, official government gazettes and internet. Data was analyzed using descriptive method.

The result of the analyses revealed that $79 \%$ of the respondents agreed that Nigeria's oil contributed to its huge debt accumulation and denied it debt cancellation. Also 65\% believed that government has been prudent in managing the nation's debt with every action taking in the interest of the people even when it failed to keep up with repayment schedules.

The dependency theory formed the basis of discussion and analyses in this work. It concluded that, oil was a major factor behind the granting of loans to Nigeria as well as responsible for fiscal irresponsibility on part of the government which led to the failure of efficient management of such loans. This paper recommended that there should be prudent management of the economy while all forms of corruption must be eradicated to bring about real development
\end{abstract}

Keywords: oil, debt management, debt forgiveness, corruption

\section{Introduction}

The struggle for political independence was majorly for economic liberation from the colonial masters whose only concern was to exploit and plunder the natural and material resources of the nation. At independence, there was high hope as people thought it would grant them control over their resources for all round sustainable development. Writing on the origin and dimension of Nigeria's debt, Nwoke (1990) opines that all the hopes and optimism of economic freedom and development became a mirage after independence. He claims, this was due to the neo-colonial political structures that were put in place by the British government before it left.

Nwoke also notes that Nigeria's economy was based largely on agricultural products like cocoa, rubber, coffee, groundnut as cash crops for export and other food crops that were for consumption like yam, cassava, maize and so on. For its lack of technological know-how, the country could not add value to these products and it had to export them, as primary products with little income in return. As a result of the above scenario, Nwoke (1990)posits that, it became largely impossible for the government to meet the yearnings and aspirations of the people since its earnings were not enough to feed not to talk of providing the basic necessities like education, good roads, potable water, electricity and so on.

He concludes that, the government had no choice like its counterpart in the African continent than to borrow money from the developed nations to carry out economic plans that would bring about positive change in the country. These loans always come with conditions and economic strategies from the creditors (Nwoke, 1990). 
Olukoshi (2002) slightly differs on this view, as he traces the debt crises to the role of international financiers, indiscriminate external borrowing and inappropriate domestic economic policies. He upholds that, the country's debt crisis was exacerbated by mismanagement of the economy which led it to the path of economic decline. Writing on IFI's involvement in Nigeria's debt crisis, Olukoshi (1990) concedes that, the conditions attached to the loans are those that would tie the debtor nations to the creditors' apron-strings and subject them to indirect control, making them perpetually dependent. This, he claims dealt untold hardship on many of the African countries, as they found it difficult to meet up with the balance of payment.

Olukoshi points out that, though Africa had incurred some debts from 1960, the debt crisis that hit the continent in the 1980s and 1990s were the worst. Prior to 1970, Africa's total debt was put below US $\$ 6$ billion and made up of long term loans from the World Bank and lending Western countries. Interest rate charges on the loans were very low then, sometimes as low as 2 percent with grace period of 3 to 10 years and repayment period of 10 to 40 years, which accounted for the low level of African debts then (1990). He further explains that, many of the African countries could not access much loans on large scale because the countries' foreign resources were earned from the sale of primary commodities, which were not significant enough to attract large-scale investment.

According to Olukoshi, another major contributor was the increase in oil price by the Organization of Petroleum Exporting Countries (OPEC) in 1973 which brought about a drastic change and hastened African countries to the debt crisis. He traces this to the increase in the price of crude that brought countries like Nigeria, Gabon, Libya and Algeria as forces to be reckoned with. This vantage position he says raised their credit worthiness and made them to receive great attention from both private and multinational capital market that were readily eager to partake in the sharing of the huge resources accruing to the African countries.

It is also pertinent to state here that the increase in price of crude opened up room for large-scale loans to African countries to free themselves from economic recession. Olukoshi (1990) attests to the fact that, International financier and private lenders also seized the opportunity to increase their interest rate which further contributed to the debt crisis of African states. This increase in interest rate he says could as well be attributed to the nature of African economies which depend heavily on foreign input and the prevalence of corrupt practices in the management of external loans (1990). Instead of getting out of the debt wood, Africa states were going back to the International Financial Institutions for more loans with the intention to revamp their economy and embark on sustainable developmental projects.

\section{Statement of the Problem}

As one of the world's major oil producers, it seemed incongruous that Nigeria became so indebted. It was owing the Paris Club roughly US 32 billion and had total external debt obligations of approximately US 36 billion (Moss, 2004). Not only did Nigeria face a huge accumulation of external debt, but ordinary Nigerians were extremely poor with over 70 percent of the population living below \$1 per day (World Bank 2005). All these situation were so in-spite of the country's huge income from oil resources. As a result of mismanagement of the resources, instead of being a blessing it became a curse. While the government failed to manage the resources well to better the living standard of the people, it served as collateral to borrow more money which could not be managed to transform the economy. These loans accumulated overtime and servicing of the debt caused untold hardship on the citizenry. Yet while other Highly Indebted Countries were considered for debt cancellation, the same oil denied Nigeria this benefit.

This paper examined the role played by Nigeria's oil in its accumulation of huge foreign debt, debt servicing/management and eventual negotiations for debt relief. This was with a view to recommend against future occurrence.

\section{Theoretical Framework and Literature Review}

The dependency theory of the political economy provided the framework of discussions in this work. According to Tade Akin-Aina (1996), studies of political economy generally begin with discussions of inequalities within the international system. These inequalities includes, first the uneven distribution of the world's resources between the rich states of the First World and the poor states of the Third World. The second is the uneven rate of development and economic growth within the international economic system, and lastly is the uneven distribution of material wealth within many states of the Third World which is far more uneven than the distribution of wealth within the states of the First World.

Dependency theory posits that the world is divided between the developed center and underdeveloped periphery. The economic gap widens over time between the two, a situation that has reduced the latter to a state of dependency. The theorists attribute the debt burden to harsh economic policies imposed on debtor nations by 
International Financial Institutions(World Bank and IMF), the conditionality that put the nation's economy at a disadvantaged position and devastating state.

The theory explains the economic dependency of a third world country like Nigeria, which has no control on the price of its product from crude oil extraction and refinery to finished products. This is based on the fact that the First World states that control international economic system control the prices of both the crude oil and the finished products to their own advantage while the producer of the product is always at the mercy of the buyers who dictate price at both ends. Also it explains the dependency of Nigeria on foreign loans as responsible for the accumulation of huge debt and the resultant effect of debt servicing on the socio-economic life of the nation.

Like many other scholars and authors, Nwoke and Olukoshi agree that, borrowing more from the international monetary market has inflicted debt burden on African countries. Their argument is that, the conditionality attached to these loans usually portray elements perceived by the borrowers as those that will return a depressed economy to the path of sustained non-inflationary growth within the shortest period (Nwoke, 1990; Olukoshi, 2002)

These conditionality include:

i. Review and curtailment of public expenditure

ii. Reduction of government subsidies

iii. Privatization of public companies

iv. Wage freezer

v. Trade liberalization

vi. Review of interest rate

vii. Devaluation of currency

All the structural adjustment packages stated above have further compounded the development rate and the external debt burden of African states while enriching the creditors.

Nwoke and Olukoshi concede to Fajana (1990) that, these packages are weapons by developed nation to control Africa economically and politically. He cites the example of Nigeria, Congo, Ghana, Kenya, Malawi, Sierra Leone and Togo among others that have implemented the adjustment program but did not achieve any significant improvement in their economies. He submits that, the socials costs of adjustment have been harsh on the generality of African people. The situation could also be blamed on the irresponsibility of African elites who are not interested in productive activities but prefers to remain subservient to imperialism, corruption, resources mismanagement and general penchant for ostentatious and white elephant projects tied to foreign loans.

In terms of origin, these loans were bilateral and institutional in nature. Bilateral sources include loans from some western countries like United Kingdom, United States of America, Germany, Netherlands and Italy. Institutional sources were mainly from the World Bank and International Monetary Fund (IMF) as the international capital markets, were not yet opened to developing countries. In terms of nature, the loans were contracted to finance projects which were to aid basic infrastructures for sustainable economic growth and development. These projects included dam for electricity and irrigation, water supply, railways, port development, technical assistance, and road networks (Ola \& Adeyemo, 1998).

The outstanding debts were minimally low in the second decade of Independence, from 1970 to 1977 . The total debt accumulation annually never exceeded N375 million. According to the Debt Management Office (DMO), Nigeria's total external debt in 1970 was N488.8 million, out of which about N59.8 million were short term trade arrears while the balance constituted short-term to long-term debts. By 1971, a large proportion of the outstanding external debt was paid, reducing the debt level to only N214.5million but this gradually increased to N350 million in 1975. By 1977, the debt accumulation had progressively increased to N496.9 million. The minimal borrowing between the period of 1970 and 1977 can perhaps be explained by the large inflow of foreign resources as a result of the 'oil boom' experienced between 1973 and 1974.

By 1978, Nigeria began to face declining revenue from crude oil sales. This was the result of oil glut, which eventually led to the scarcity of foreign exchange. This scarcity can also be explained by government's pattern of expenditure which were not informed by economic decisions. Due to the fall in the price of crude oil, the government could no longer sustain the established pattern of spending between 1974 and 1976 without recourse to external financing (Ola \& Adeyemo, 1998). Hence in 1978, Nigeria, applied for the 'jumbo' Euro-market loans of about $\$ 2.2$ billion during the tenure of Gen. Olusegun Obasanjo. This was the biggest loan ever contracted by the country at once (www.newstartinnigeria.org.) 
The third decade of Nigeria's independence was indeed a period of external balance crisis. Starting from an almost non-existence debt burden in 1974, to more than triple debt burden of about $\$ 2.2$ billion within a period of three years. At the end of 1983, Nigeria became one of the largest debtor nation in the world and indeed the largest in sub-Saharan Africa.

The period between 1981 and 1983 was characterized by economic recession but, due to established pattern of spending during the 'oil boom' era, it became difficult to reduce import bill even though there was a drastic fall in export revenues from crude oil sales. The outcome of this was rapid accumulation of short-term trade debts on letters of credit, bills for collection and even open accounts. The trade arrears became so huge and unserviceable, that the external creditors lost confidence in the ability of the economy to service the debt (Ola \& Adeyemo, 1990).

A major factor that worsened the debt crisis as highlighted by Olukoshi was mismanagement of the economy by those in control. This was coupled with the fall in price of primary commodity, the role of international financiers, indiscriminate external borrowing and inappropriate domestic economic policies (Olukoshi, 2002). Ugolor and Atakpu (2003) traced the crisis to political instability and lack of continuity in government as a result of military seizure of power from 1983 by Major General Muhammadu Buhari to 1999 administration of Gen. Abdusalami Abubakar (www.newstartinnigeria.org).

Although, there was External Loan Decree of 1970, which the Federal Government promulgated to check the unwarranted sourcing of loans, which was amended in 1978, it failed to achieve the desired result due to lack of continuity in government occasioned by military seizures of power, while the debt continued to increase (Debt Management Office, 2005).

Table 1. Structure of Nigeria's external debts outstanding (1997-2007) (US \$ Millions)

\begin{tabular}{ccccccc}
\hline Years & Multilateral & Paris Club & London club & Promissory Notes & Others & Total \\
\hline 1997 & 4,373 & 18,980 & 2,043 & 1,613 & 79.2 & 27,088 \\
1998 & 4,237 & 20,839 & 2,043 & 1,597 & 65.8 & 28,773 \\
1999 & 3,933 & 20,534 & 2,043 & 1,486 & 69.3 & 28,065 \\
2000 & 3,460 & 21,180 & 2,043 & 1,447 & 143.8 & 28,274 \\
2001 & 2,798 & 22,093 & 2,043 & 1,292 & 122 & 28,348 \\
2002 & 29,606 & 25,381 & 1.441 & 115.3 & 55.6 & 30,9921 \\
2003 & $3 \mathrm{~b}$ & $27.5 \mathrm{~b}$ & $1.4 \mathrm{~b}$ & $0.9 \mathrm{~b}$ & $0.05 \mathrm{~b}$ & $32.9 \mathrm{~b}$ \\
2004 & $2.8 \mathrm{~b}$ & $30.9 \mathrm{~b}$ & $1.4 \mathrm{~b}$ & $0.8 \mathrm{~b}$ & $0.05 \mathrm{~b}$ & $35.9 \mathrm{~b}$ \\
2005 & $2.8 \mathrm{~b}$ & $30.9 \mathrm{~b}$ & $1.4 \mathrm{~b}$ & $0.8 \mathrm{~b}$ & $0.05 \mathrm{~b}$ & $35.9 \mathrm{~b}$ \\
2006 & 2.6 & 0.00 & 0.00 & 509.01 & 101.10 & $3.54 \mathrm{~b}$ \\
2007 & $3,080.91$ & 0.00 & 0.0 & 0.0 & 388.4 & $3.65 \mathrm{~b}$
\end{tabular}

Sources: (1) Central Bank of Nigeria (Annual Report 2005); (2) National Bureau of Statistics (Statistical Bulletin 2005); (3) Debt Management Office (The Punch, August 5, 2009)

This growth indicates the assumption of non-guaranteed debt of the government, which accounted for almost two-third of the increased cross currency re-valuation, brought about by the fall in dollars contributed about $27 \%$ to the increase in external debt. By comparison, new net borrowing accounted for only $8 \%$ of the increase in debt stock as of December 1996. According to President Olusegun Obasanjo, the total of all debt secured by Nigeria from all sources from the late 1970's to the end of the 1990's was less than \$13 billion. It is important to note that by the time Nigeria paid her debt in 2007, the creditors had reaped enormous dividend of almost five times the initial outlay.

\section{Nigeria's Debt and the Oil Factor}

Underlying the debate about Nigeria's worthiness for debt relief is the belief of western nations that Nigeria is a wealthy oil nation that merely needs to improve governance and root out corruption to spur domestic development. As Sachs (2000) points out, Nigeria hardly qualifies as "rich" country when one factors in its vast population. Indeed, Sachs estimates that in 2000, oil export earnings only amounted to about $\$ 280$ per capita annually. Aside 
the basic argument that there is simply not enough oil wealth to go around, there are also numerous characteristics of oil as a commodity and the nature of oil production that create development problems for a highly oil-dependent nation. As Ross (2003) points out, there are five ways in which oil wealth can hurt the poor: by causing economic volatility; by crowding out the manufacturing and agricultural sectors; by heightening inequality; by inducing violent conflict; and by undermining democracy. Each of these factors was apparent in Nigeria. There was a pattern of government spending that closely follows fluctuations in the value of oil exports, a situation where the spending behavior of the government has magnified the impact of oil-related shocks on the economy. Also, the nature of the oil industry refused to fill the gap created in its consequent reduction in agro-allied industry. As Ross (2003) asserts, oil producing nations have a greater predisposition to income inequality which is demonstrated by the growing inequality in Nigeria. He posit that, the dominance of the oil sector weakened the local manufacturing sector and prevented the growth of an urban middle class which is the traditional foundation for emerging democratic institutions. He also points out that significant oil revenues have allowed the Nigeria government to maintain low taxation rates and distributes federal revenues in the form of patronage, which reduced the pressure for more accountable governance.

Thus, while Nigeria's creditors continued to hold firm to the belief that Nigeria is a wealthy oil producer, it is important to consider the lack of development and the extreme poverty of the country's population. As shown above, oil has failed to stimulate economic growth and development. The problem was compounded by longstanding mismanagement of the country's oil revenues and the under-development of the sector.

Although Osoba (1996) says, corruption is not a Nigerian creation, and the way it is manifested is dependent on the mode by which capital is accrued. Simon (2002) is of the view that, the 'culture of bribery and corruption' explains why the country was highly indebted in spite of its oil wealth. .As Osoba earlier points out, the problems in Nigeria has clearly been the "total lack of budgetary discipline and financial accountability" related to the domestic political structure. In the same vein, Watts (2003) posits that, the nature of the "oil complex" through which transnational corporations are sources of rents and petro-revenues to the local and federal governments also played a key role in fostering corruption. He further asserts that, Nigeria has witnessed "a corrupt and undisciplined oil-led development" in which transnational companies, through joint ventures with the state, "determine the distribution of royalties and rents" $(2003,5)$.

While oil production has provided a domestic means for corruption and fraudulent activities by state officials, Nigeria's important position in the global oil sector has been another avenue for corrupt leaders to extend their reach outside local coffers and into international financial markets. As Atakpu $(2003 ; 4)$ states, "most of Nigeria's debts were irresponsibly contracted by military dictators who plundered the nation's resources including external loans for selfish ends.

It is ironical that Nigeria's most valuable resources added to the country's debt problems. However, Kretzman and Nooruddin $(2005 ; 4)$ explaining the relationship between oil and debt posit, "increasing oil production and exports lead to increasing debt'". They explain that, the global oil economy improves the ability of countries to make debt payments while at the same time increasing their debt. This is said to be the result of three key factors:

(1) structural incentives for, and direct investments in the oil industry by multilateral and bilateral institutions (particularly the World Bank and its sister organizations); (2) Oil fueled fiscal irresponsibility:- both in the West by creditors eagerness to lend to nations perceived as oil rich, and in the South by unwise fiscal policies; and (3) the volatility of the oil market.

The last two factors are particularly pronounced in Nigeria. As Ross (2003; 9) rightly puts it, Nigeria's system of intergovernmental finance is complicated and makes fiscal management extremely cumbersome. According to Kretzman and Nooruddin, while declining oil revenues were the reason for the financing gap, Nigeria's oil resources were also the assets by which the government was able to leverage to secure international loans. Thus, the fact that Nigeria is dependent on oil contributed to the country's accumulation of external obligations and also failure to meet up with repayment schedules.

\section{Analysis and Discussion}

In addition to the above, an interview was conducted on some high ranking officers of the DMO to know if the Nigerian government was prudent in managing the country's debt considering its huge income from oil, the resources which according to the IFIs should be enough to pull the nation out of debt. The result showed that, $65 \%$ of the respondents agreed to the country's prudency while 35\% disagreed. Some of the respondents said the government has always manages the country's debt in a prudent manner regardless of who is in power both under the military and civilian regimes. They said government will always consider the best interest of the people before taking any action on debt management. This interest they claimed was responsible when in time past the 
government especially under military regime failed to keep up with repayment schedule as leaders must set priority right. On the other hand those who disagreed blamed such failures to keep up with repayment schedules as responsible for the debt accumulation. They explained that the level of corruption was so high that larger percentage of public funds were going to private pockets thereby denying the people the necessary social amenities like road networks, electricity, potable water, education, health among others all of shot up the poverty level of the country. They concluded that past Nigerian leaders were reckless and wasteful in managing the country's resources as well as its debt prior to return to democracy in 1999. They however agreed that the regime of President Olusegun Obasanjo took proactive steps to reschedule the nation's debt, the efforts that resulted in the eventual debt relief and buy-backs. The government after the payment also put up some measures to ensure debt sustainability and avoid a relapse into the pre-exit situation. The DMO has developed a National Debt Management Framework (NDMF) to guide the policy and strategy for external and domestic borrowings by the federal and state governments and their agencies.

The NDMF contains specific guidelines for borrowing, designed not only to limit borrowings to sustainable level, but also to ensure that the funds are judiciously put to use and lead to growth, employment and poverty reduction. In addition, DMO is working closely with the Ministry of Finance, Central Bank of Nigeria, the National Planning Commission and other agencies to conduct annually, a Debt Sustainability Analysis (DSA) to keep track of the statistics and dynamics of public debt.

\section{Conclusion and Recommendations}

This paper concluded that, Nigeria as a result of mismanagement was unable to judiciously put the loans to use for the purposes which they were contracted to be able to achieve sustainable development. This coupled with corruption and bad leadership made it impossible for the country to meet up with debt service obligations.

It is also a fact that the Nigeria's inability to efficiently manage its vast oil resources contributed to its debt accumulation as the resources served as collateral in contracting the loans considering the West strategic interest as major consumer of the nation's oil products.

It is therefore recommended that it is high time the government became prudent in the management of the economy while all forms of corruption must be eradicated to bring about real development. The bane of the problem was mismanagement of resources coupled with corruption which were the reasons why the loans failed to translate to development. Finally, a policy should be formulated to discourage frivolous recourse to external loans at all tiers of government. Government should ensure that loans (internal or external) taken for developmental purposes are judiciously put to use while repayment schedules are strictly adhered to.

\section{References}

Africa Confidential. (2005, March 4). Time is Running Out for President Obasanjo to Make a Lasting Difference, $46(5)$.

Atakpu, L. (2003). Why Nigeria`s Debt Should be Cancelled. Jubilee South Journal. Retrieved January, 2007, from http://jubileesouth.org/journal/nigeria.htm

Capps, G. (2005). Redesigning the Debt Trap. International Socialism, 107, 24.

Central Bank of Nigeria. (1986). Annual Report and Statement of Accounts.

Debt Management Office. (2008). National Debt Management Framework (2008-2012). Retrieved March, 2011, from http://www.dmo.gov.ng

Fajana, O. (1990). The Dynamics Nigeria s Negotiations with the London and Paris Club. Lagos Nigeria: NIIA, Malthouse Press Limited.

International Monetary Fund. (2005). Poverty Reduction and Growth Facility. Retrieved January, 2007, from http://www.imf.org/externa/np/exr/facts/prgf.ht

Kretzmann, S., \& Nooruddin. (2005). Drilling into Debt: an Investigation of the Relationship Between Debt and Oil. Oil Change International. Retrieved November, 2007, from http://www.priceofoil.org/uploads/media/DrillingIntoDebt.pdf

Moss, T., Scott, S., \& Nancy, B. (2004). Double-Standards, Debt Treatment, and World Bank Country Classification: the Case of Nigeria. Center for Global Development.

National Concord. (1986, 15 June).

Ndikumana, L., \& James, K. B. (2002). Public Debts and Private Assets: Explaining Capital Flight from Sub-Saharan African Countries. Political Economy Research Institute. 
Nwoke, C. N. (1990). The Origins and Dimension of Nigeria 's External Debt. Lagos Nigeria: NIIA, Malthouse Press Limited.

Ola, C. S., \& Adeyemo, A. J. (1998). Public Finance in Nigeria. Lagos Nigeria: CSS Limited.

Olukoshi, A. (1990a). Debt Equity Conversion as an Instrument of Structural Adjustment in Nigeria. Lagos Nigeria: NIIA, Malthouse Press Limited.

Olukoshi, A. (1990b). The Management of Nigeria's External Debt: Issues and Problems. Lagos Nigeria: NIIA, Malthouse Press Limited.

Olukoshi, A. (1990c). The Role of IMF and World Bank in the Management of Nigeria's Foreign Debt. Lagos Nigeria: NIIA, Malthouse Press Limited.

Osoba, S. O. (1996). Corruption in Nigeria: Historical Perspectives. Review of African Political Economy, 69 , 371-386. http://dx.doi.org/10.1080/03056249608704203

Rieffel, L. (2005). Resolving Nigeria's Paris Club Debt Problem: a Case of Non-Performing Creditors. The Brookings Institution.

Ross, M. L. (2003). Nigeria's Oil Sector and the Poor. UCLA Department of Political Science. Retrieved November, 2006, from http://www.polisci.ucla.edu/faculty/ross/NigeriaOil.pdf

Sachs, J. (2000, June 14). Give Poor Nigeria a Chance. Financial Times.

The Economist. (2005a, October 21). Nigeria Economy: Clean Slate. The Intelligence Unit.

The Economist. (2005b, October 24). Nigeria Economy: Debt Deal. The Intelligence Unit.

United Bank for Africa. (1988, September). Monthly Business and Economic Digest.

\section{Copyrights}

Copyright for this article is retained by the author(s), with first publication rights granted to the journal.

This is an open-access article distributed under the terms and conditions of the Creative Commons Attribution license (http://creativecommons.org/licenses/by/3.0/). 